\title{
МУЗЫКА И ЕЕ ЗНАЧЕНИЕ В РОМАНЕ М.А. БУЛГАКОВА «МАСТЕР И МАРГАРИТА»
}

\author{
А.Н. Комисаренко

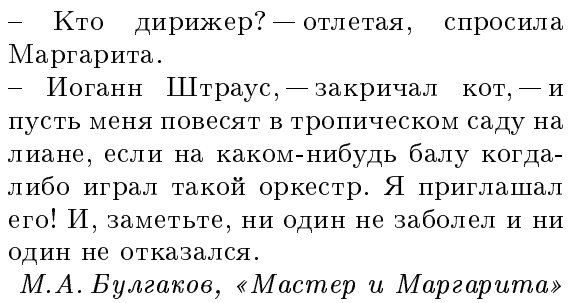

Роман М.А. Булгакова «Мастер и Маргарита» - произведение сложное и многослойное, спектр идей, проблем и смыслов, которые были заложены в сюжетную канву романа, необычайно широк. На тематическом уровне сюжет романа развивается в самых разнообразных плоскостях - от бытовых коллизий и критики чиновничьей бюрократии («обыкновенные люди ... в общем напоминают прежних ... квартирный вопрос только испортил их» $[1$, с. 306]), до глубокого осмысления метафизических истин на уровне борьбы добра и зла, идеального и материального («что бы делало твое добро, если бы не существовало зла, и как бы выглядела земля, если бы с нее исчезли тени?» [1, с. 466]).

Широко бытует мнение, что роман М.А. Булгакова «Мастер и Маргарита» написан в форме «романа в романе». Действия и события в нем разворачиваются параллельно в двух мирах. Это приезд Воланда в Москву для проведения в столице Бала Сатаны - с одной стороны, и своего рода литературная трактовка библейских сказаний о суде и казни Иешуа, странствующего философа, который проповедовал приход

Актуальні проблеми духовності:

зб. наук. праць / Ред.: Я.В. Шрамко

Вип. 10. - Кривий Ріг, 2009, 254-265 
Нового Царства Бога на земле, - с другой. Эти две сюжетные линии перекрещиваются в образе Воланда, который видел Иешуа, завтракал с И. Кантом и, наконец, прибыл в Москву первой половины ХХ ст.

Необходимо отметить, что роман «Мастер и Маргарита» неоднократно был в центре внимания как литературоведов, так и философов. О творчестве М.А.Булгакова написано большое количество публикаций, статей и монографий. В целом авторы чаще всего трактуют литературное наследие писателя в двух-трех аспектах: историческом (история России в авторском осмыслении), метафизическом (религиозные мотивы, символика, библейская мифология), морально-этическом (добро и зло, проблема нравственности и власти, материальное и идеальное).

Большой интерес представляет статья В.С. Хазиева «Кант и Воланд» [7], который анализирует теологическую и философскую стороны романа. Но в ней делается акцент на метафизике морали и почти не рассматриваются категории Прекрасного и Эстетического. Такой подход не дает полного, основательного разбора сущности и структуры этого литературного шедевра, поскольку, на наш взгляд, творчество М.А.Булгакова должно быть рассмотрено с этико-эстетических позиций, не забывая, помимо религии и нравственности, о роли искусства.

Такие авторы, как П.С.Попов, И.Ф.Бэлза, П.И. Палиевский рассматривают творчество М.А.Булгакова сквозь призму его биографии и связывают ключевые моменты, место действия («нехорошая квартира № 50») и повороты сюжета романа «Мастер и Маргарита» с фактами его жизни. Но если сместить акценты и посмотреть на развитие сюжета в другом спектре, взяв иную точку отсчета, например, феномен музыки, то можно обнаружить много любопытного. Такой подход является вполне оправданным и продуктивным, если, в частности, принять во внимание музыкальное образование писателя. Он прекрасно играл на фортепиано, хорошо знал мировую музыкальную культуру, был знатоком оперы, что не могло не повлиять на его творческую деятельность в целом. И главный роман его жизни - яркий тому пример. Оказывается, «Мастер и Маргарита» не только композиционно и структурно оформлен как «роман в романе», но, более того, на протяжении всего действия мы можем выделить то, что можно охарактеризовать как аналог цельного музыкального произведения, написанного по форме 3 -х частной сонаты. В семиотическом и символическом плане данное литературное произведение скрывает в себе третий драматический пласт - музыку в форме романа, а точнее-«музыку в романе». Естественно, этот аспект данного произведения передается 
словесными формулами и художественно-литературными приемами.

Целью данной статьи является исследование образно-символического воплощения «музыки в романе» (музыкального подтекста) произведения М.А. Булгакова «Мастер и Маргарита», с учетом различного рода фактов, событий и описаний, которые так или иначе связаны с музыкой и музыкальным искусством вообще.

С первых страниц романа мы узнаем, что один из ключевых героев носит фамилию «Берлиоз». Миша Берлиоз - не просто однофамилец великого композитора Гектора Берлиоза, но и символическое воплощение музыкальной атмосферы романа в целом. Можно обратить внимание на любопытный факт: по своему идейному содержанию, тематике и образному значению роман М.А.Булгакова близок к «Фантастической симфонии» Г. Берлиоза, написанной в 1830 г. Можно даже предположить, что роман «Мастер и Маргарита» является в некоторой степени символическим отражением программной канвы и основного замысла симфонии Г. Берлиоза.

Действительно, в «Фантастической симфонии» так же переплетены темы любви и страсти (1 часть Largo), звучит тема бала (2 часть Adagio), на котором встречаются влюбленные. Точно так же, в этих произведениях перекрещиваются мотивы страдания и смерти, присутствует шабаш ведьм (4 часть Allegretto, 5 часть Larghetto. Allegro). Гектор Берлиоз изложил программный замысел своего творения следующим образом: «Молодой музыкант с болезненной чувствительностью и горячим воображением отравляется опиумом в припадке любовного отчаянья. Наркотическая доза, слишком слабая для того, чтобы вызвать смерть, погружает его в тяжелый сон, сопровождаемый странными видениями, во время которого ощущения, чувства и воспоминания претворяются в больном мозгу в музыкальные мысли и образы. Сама же любимая женщина становится для него мелодией и как бы навязчивой идеей (idee fixe), которую он находит и слышит повсюду» (см.: [3, с. 48]). «Фантастическая симфония» Гектора Берлиоза заканчивается сатанинским танцем, смысл которого перекликается с вальпургиевой ночью из «Фауста» И.В.Гете и, конечно же, с балом Сатаны из романа «Мастер и Маргарита» М.А.Булгакова.

Симфония дышит смертью и наркотическим бредом. Не случайно, ведь, и Миша Берлиоз, председатель МАССОЛИТа, погибает под колесами трамвая. Его смерть в начале романа-отправная точка всех дальнейших мистических событий произведения. Персонаж романа заплатил высокую цену за свои идеологические и атеистические взгляды: Воланд отправляет его в небытие. Наказание председателя 
МАССОЛИТа Князем Тьмы имеет параллель с другим симфоническим произведением Гектора Берлиоза - «Осуждение доктора Фауста», суть которого заключается в том, что смертным не дано тягаться с высшими силами на равных и за все наступает расплата. По случайному стечению обстоятельств отец Гектора Берлиоза для своего сына готовил карьеру медика [6, с.171]. М.А.Булгаков, как известно, был профессиональным доктором и занимался медицинской практикой. Как не вспомнить «о причудливо тасуемой колоде карт»!

Фамилия финдиректора варьете Григория Даниловича Римского в романе, вполне возможно, является производной от фамилии композитора Н.А.Римского-Корсакова. И это также вряд ли случайно. Уникальность музыкального творчества этого композитора заключается в оперно-симфонической интерпретации сказок («Садко», «Снегурочка», «Кащей Бессмертный», «Сказка о царе Салтане», «Золотой петушок», «Шехеразада). В сказках всегда присутствует мистика, тайна, борьба добра и зла. Наибольший интерес для темы нашего исследования представляет сказка-опера «Золотой петушок» (1907), которую Н.А.Римский-Корсаков написал не просто как музыкальный шедевр, а как политический памфлет или сатирический фельетон на царский режим, высмеивая бюрократизм чиновников [6, с. 348-349]. Говоря о музыкальных сказках композитора применительно к рассматриваемому произведению, можно сказать, что роман М.А.Булгакова «Мастер и Маргарита» тоже своего рода сказка, очень сложная сказка для взрослых. В ней реальное и нереальное переплетено так, чтобы наиболее рельефно выделить несовершенство советского общества булгаковского времени. Следует сказать, что опера «Золотой петушок» запрещалась цензурой, ее нельзя было ставить во многих театрах. В этом также имеется определенная параллель с произведением М.А.Булгакова. Его роман «Мастер и Маргарита», по сути, тоже памфлет, но на сталинский режим и атеистическую идеологию партии. Автором саркастично высмеяны домоуправ-взяточник Босой и председатель акустической комиссии Семплеяров. Показан произвол чиновников и бюрократов, пошлость, мещанство, снобизм (Варенуха, Лиходеев). Но в первую очередь писатель высмеивает псевдоинтеллигенцию и графоманов «Дома Грибоедова».

В романе есть и третий герой с фамилией композитора. Это доктор, психиатр, профессор Александр Николаевич Стравинский. Он лечил от шизофрении Ивана Бездомного, и к нему в клинику направлялись чиновники городского Зрелищного филиала, страдавшие навязчивым хоровым пением из-за проделок Коровьева. Естественно, лечить от пе- 
ния может только доктор с такой музыкальной фамилией! В основе творчества композитора И.Ф. Стравинского лежит древний фольклор, народные песни, мифология, мистика древних славян и греков. Параллельно в его произведениях встречаются и религиозно-духовные мотивы, размышления над смыслом существования грешного человека. Широкое признание и популярность получили такие оперно-симфонические шедевры, как «Жар-Птица», «Петрушка», «Орфей», «Царь Эдип», «Священное песнопение», «Заупокойное песнопение». Тематическая основа творчества Стравинского во многом перекликается с подтекстом романа Булгакова. Мистико-религиозное начало - движущая пружина борьбы героев, их страстей, эмоций и чувств. И композитор, и писатель близки художественно-метафизическим осмыслением сущности человека как личности и общества в целом.

Непосредственное отношение к музыке имеет и прозвище Коровьева из свиты Воланда-«Фагот». Звуковую характеристику этого музыкального инструмента замечательно излагает Н.Н. Зряковский в «Общем курсе инструментоведения». Звучание фагота полное, густое, несколько хриплое и грубоватое, а в среднем и в высоком регистре матовое, бледное, гнусавое [2, с.251]. Звуковые свойства инструмента прекрасно соотносятся с такими чертами характера Коровьева, как хитрость и насмешливость, граничащая с сарказмом. Коровьев-Фагот на самом деле неудачно пошутивший рыцарь, который оплачивает счет за не совсем удачный каламбур о свете и тьме. Образ Коровьева, подобно звуковому диапазону фагота (от грубого хрипа до бледной гнусавости), трагикомичен.

Таким образом, на наш взгляд, фамилии композиторов, которые М.А.Булгаков дает персонажам своего романа, символически подчеркивают главный замысел автора: в мистико-философском ключе гротескно высмеять погрязшее в лицемерии и разврате современное ему общество и утвердить идею Чистой Любви как главного проявления Мировой гармонии.

С первой главы романа можно выделить музыкальные моменты. В беседе Берлиоза и Бездомного Воланд замечает, что Штраус «просто смеялся над этим доказательством» (имеется в виду Кантовское доказательство бытия Бога). Композитор Иоганн Штраус в последствии появляется на балу у Сатаны в качестве дирижера «лучшего в мире оркестра». И.Штраус приобрел известность как автор венских придворных вальсов [4, с. 645]. Но почему же «король вальсов» смеется над шестым доказательством Канта? Ответ можно найти в биографии композитора. В начале своей композиторской карьеры, обучаясь у ка- 
пельмейстера Йозефа Дрехслера, И. Штраус «мечтал о более ,земной музыке“» [6, с. 269]. Он тяготел не к высоким духовным кантатам, а ко всему обыденному и популярному. Сочиняя свои «слащавые» вальсы, он пытался передать в мелодиях «бурлящую радость бытия» $[6$, с. 273], что так роднит его с Воландом, для которого «недоброе таится в мужчинах, избегающих вина, игр, общества прелестных женщин, застольной беседы. Такие люди или тяжко больны, или втайне ненавидят окружающих» [1, с. 361]. Вальсы Штрауса наполнены земными и материальными радостями. Они слишком далеки от духовного аскетизма и альтруизма, которые проповедовал Иешуа. Музыка композитора плотская, ведь она должна заставить тело танцевать, что мы и видим на балу у Воланда. В противоположность «плотским вальсам», в романе «Мастер и Маргарита» встречается религиозный напев «Аллилуйя». Впервые его исполняет Грибоедовский джаз-оркестр (Глава 5), вторично этот напев звучит из патефона в больнице (Глава 18), в третий раз его исполняет джаз-банд на балу у Сатаны, где данная тема противостоит оркестру Иоганна Штрауса (Глава 23). Традиционный перевод напева «Аллилуйя» - «Хвалите Господа» берет начало из ритуального исполнения псалмов $[4$, c. 26]. Тема «Аллилуйя» контрастирует с вальсами Штрауса, выражая тем самым конфликт между Хвалением Бога и балом Сатаны. Пение духовных псалмов противостоит телесным движениям. Этими полярными началами пронизан драматический конфликт двух тем, как в сонатной форме - 1-я Главная Партия Воланда (вальс на балу) контрастирует с 2-й Побочной Партией Бога (напев «Аллилуйя»). Такое противостояние характерно для сонатной формы с двумя конфликтующими темами.

В Главе 4, когда Иван Бездомный гонится за свитой Воланда, мы вновь встречаем намек на танец ( В каждом из этих окон горел огонь под оранжевым абажуром, и из всех окон, из всех дверей, из всех подворотен, с крыш и чердаков, из подвалов и дворов вырывался хриплый рев полонеза из оперы „Евгений Онегин“» $[1$, с. 256]). Именно под хриплый рев польского танца Воланд и его компания исчезают с поля зрения несчастного поэта. Танец - своего рода насмешка над тщетностью и наивностью пролетарского литератора-атеиста. По требованиям классической композиции в 1-й части сонатного цикла (экспозиции) между Главной Партией (ГП) и Побочной Партией (ПП) должна быть Связующая Партия (СП), своего рода логический переход, модуляция, сглаживающая резкий контраст и выравнивающая общую архитектонику.

При внимательном прочтении текста мы неоднократно столкнемся 
с жанром марша. Например, марш кота Бегемота в Главе 12:

А тут еще кот выскочил к рампе и вдруг рявкнул на весь театр человеческим голосом:

- Сеанс окончен! Маэстро! Урежьте марш!!

Ополоумевший дирижер, не отдавая себе отчета в том, что делает, взмахнул палочкой, и оркестр не заиграл, и даже не грянул, и даже не хватил, а именно, по омерзительному выражению кота, урезал какой-то невероятный, ни на что не похожий по развязности своей марш $[1$, с. 309].

Далее в Главе 19 появляется похоронный марш в честь Миши Берлиоза. И, наконец, марш в честь Маргариты на балу у Воланда в Главе 21. Марш - своеобразный жанр, ибо его главные особенности - строгая размеренность темпа и четкий ритм [4, с.328]. Маршевые ритмы служат для обеспечения синхронного движения большого числа людей (движения войск в строю, различные шествия, митинги). СП маршевых ритмов в романе, скорее всего, имеет значение символической передачи либо обезличивания личности в толпе, где доминирует идеологический атеистический прессинг на индивида (похороны Миши Берлиоза, марш Бегемота), либо для создания определенного настроения группы персонажей. Например, столкновение свиты Воланда и всего атеистического социума смертных москвичей. Как и марш, вальс тоже имеет четкую ритмичность, но вальс более танцевален, тогда как марш ближе к строевому шагу и ходьбе. Тема «Аллилуйя» контрастирует как с вальсом, так и с маршем, ведь для духовных псалмов характерна умиротворенная мелодика в среднем, спокойном темпе.

Итак, мы определили 1-ю экспозиционную часть сонатной формы «музыки в романе» главного булгаковского произведения: ГП - вальсы И.Штрауса, СП - марш, ПП - псалом «Аллилуйя».

2-я часть сонатного цикла (в композиции она имеет название «разработка») представляет собой нагнетание энергии, событий и коллизий. Выступление Воланда в варьете, переполох в Москве, мистические события в различных учреждениях, - все это ускоряет динамику сюжетной линии. Но и здесь мы встречаем некоторые интересные моменты, связанные с музыкальным искусством.

Средняя часть, разработка, представляет собой сплошную джазовую импровизацию, наполненную диссонансами, додекафоническими моментами, хаосом звуков и мелодическими образами. Если 1-я часть выдержана в манере классического изложения материала, то для 2- 
й части характерен полный отказ от канонов классики. Все начинается после того, как Маргарита, использовавшая крем Азазелло по назначению, влетела в квартиру литературного критика Латунского и молотком принялась ломать рояль (Глава 21). Можно себе представить, какие это были звуки и удары, когда клавиши трешали под тяжестью молотка, рвались струны, разлетались щепки! Это напоминает музыку польского композитора К. Пендерецкого, который в свое произведение «Флуоресценции» вводит в большой симфонический оркестр необычайное звучание: («пилка дерева пилой, стук пишущей машинки, шлифовка стекла напильником, вой сирены» [6, с. 587]). Но полная кульминация такого музыкального безобразия встречается в Главе 23 на балу у Сатаны:

На эстраде за тюльпанами, где играл оркестр короля вальсов, теперь бесновался обезьяний джаз. Громадная, в лохматых бакенбардах горилла с трубой в руке, тяжело приплясывая, дирижировала. В один ряд сидели орангутанги, дули в блестящие трубы. На плечах у них верхом поместились веселые шимпанзе с гармониями. Два гамадрила в гривах, похожих на львиные, играли на роялях, и этих роялей не было слышно в громе, и писке, и буханьях саксофонов, скрипок и барабанов в лапах гиббонов, мандрилов и мартышек [1, с.404-405].

По нашему мнению, М.А. Булгаков неспроста подчеркивает это зверское уничтожение божественной гармонии, где скрывается символизм религиозного песнопения по правилам церковной композиторской техники.

2-я часть «музыки в романе»- словно сатанинский Джинн, выпущенный из бутылки, и это логично, ведь на балу у Сатаны собралась разношерстная компания «самоубийц, отравительниц, висельников и сводниц, тюремщиков и шулеров, палачей, доносчиков, изменников, безумцев, сыщиков, растлителей» [1, с.404]. Так что бал Воланда постепенно превратился в балаган или в дешевый трактир, в котором, как и в любой «забегаловке», не до высоких «философских материй». Разве что у М.А. Булгакова в романе не хватает шансона, точнее, главного его хита под названием «Мурка». Вспомним популярный напев: «Сколько я зарезал, сколько перерезал. Сколько душ невинных загубил». Вся эта кутерьма и дисгармонический хаос прерываются трубным ревом из крепости Антония в Ершалаиме (Глава 26). Иуда не услышал предупреждающий сигнал судьбы и во мраке весенней ночи 
был убит за предательство. Из библейского прошлого в атеистическую Москву словно врываются сакральные звуки.

С этого момента начинается 3 -я часть сонатного цикла - Реприза и Кода, в которой доминирующую роль уже играет тема Бога. Последняя часть «музыки в романе» проходит в атмосфере композитора Франца Шуберта.

О, трижды романтический мастер, неужто вы не хотите днем гулять со своею подругой под вишнями, которые начинают зацветать, а вечером слушать музыку Шуберта? Неужели ж вам не будет приятно писать при свечах гусиным пером? [1, с. 482].

Слова Воланда к мастеру в конце романа - как заключительная часть и каденция ко всему произведению. Музыкальное творчество одного из первых романтиков XIX века Ф. Шуберта становится завершающим аккордом всего сонатного цикла в романе «Мастер и Маргарита». Личность Ф.Шуберта вызывает в памяти ряд гениальных произведений. Прежде всего, его вокальные шедевры: песня на литургический текст «Ave Maria» и цикл песен «Зимний путь», который был написан композитором за год до смерти и символизирует прощание с земным материальным миром. Реприза получается усеченной, сокращенной и неполной, так как тут мы уже не встречаем ни мотива Дьявола, ни маршеобразных ритмов. Как это все не клеится с дисгармонией, царившей на балу у Сатаны! Повелитель Теней ни с того, ни с сего ублажает слух «трижды романтического» мастера мелодичным, одухотворенным и оторванным от всего земного Шубертом, чье композиторское мастерство создало непревзойденный памятник музыкальной композиции на псалом «Ave Maria». C чего бы это? K тому же, содержательная часть и символическое значение «Ave Maria» непосредственно перекликается с напевом «Аллилуйя». Парадокс?

М.А.Булгаков, в отличие от И.В.Гете, создает новый образ Сатаны, непривычный для традиционного восприятия. Мефистофель Гете-саркастичный, циничный и тщеславный. Его логика и мышление в корне иные, чем у булгаковского Воланда. Мы соприкасаемся с двумя трактовками образа зла в мировой литературе. Данная проблема требует отдельного исследования, здесь же мы только заметим, что, если убрать рога и копыта, то из Мефистофеля выйдет «реалист, метафизик, эмпирик и позитивист» [5, c. 180]. Булгаков взял эпиграфом для романа основную идею «Фауста», которая провела четкую границу между Мефистофелем и Воландом. 
Зло Мефистофеля плотское, примитивно-наглядное и хитрое. Оно очерчено очень резко в самых традиционных и понятных штрихах, оно «вечно хочет зла». Мефистофель издевается над смертными людьми, играет на их самых примитивных страстях, высмеивая высшее творение Бога. Хотя в составлении своих силлогизмов при аргументации собственной сущности он с легкостью может справиться с котом Бегемотом. Зло Воланда тоже плотское и низменное, но оно скорее рационально-критическое, чем примитивно-циничное. Воланд не ненавидит людей, а только наблюдает за ними, сомневается в них и проверяет их:

Но умоляю вас на прощанье, поверьте хоть в то, что дьявол существует! О большем я уж вас и не прошу. Имейте в виду, что на это существует седьмое доказательство, и уж самое надежное! И вам оно сейчас будет предъявлено [1, с. 250].

В то же время, на протяжении всего романа он ни разу не делает выпадов в сторону Бога, прекрасно осознавая, что земного шара без теней и «голого света» в абсолюте здесь, в материальном мире, не может быть никогда. М.А. Булгаков изобразил зло в какой-то мере разумным, а точнее-сомневающимся и мыслящим, как бы парадоксально это ни звучало. Полемика Воланда против И. Канта берет свое начало из стремления Сатаны обосновать зло рациональными методами. Мефистофель - эмпирик-позитивист, Воланд-логик-рационалист. Недаром Левий Матвей назвал Повелителя теней «старым софистом». Зло Воланда «вечно совершает благо»! Вот откуда возникает «вечный приют» для Мастера и Маргариты, наполненный музыкой Ф. Шуберта («По этой дороге, мастер, по этой»). Вокально-мелодическая музыка Шуберта ставит «последнюю точку» всем тем коллизиям, которые возникли с первыми вальсовыми ритмами Штрауса в начале повествования.

Подводя итоги нашему исследованию, можем констатировать следующее: 1) роман М.А. Булгакова «Мастер и Маргарита» с точки зрения структуры сюжета - это «роман в романе», на музыкально-образном же уровне он представляет собой своего рода «музыку в романе»; 2) композиция «музыки в романе» может быть представлена как классическая 3-х-частная сонатная форма (экспозиция, разработка, реприза), в которой отчетливо можно выделить контрастные темы Главной и Побочной партий (танцевальные жанры-символ бала Сатаны, а напев «Аллилуйя» и музыка Ф.Шуберта - «Ave Maria» - символ духовного и божественного). Связующей партией является здесь жанр 
марша; данная музыкальная сонатная форма органично вплетена в ткань литературной формы; 3) кульминационным моментом «музыки в романе» непосредственно является бал Сатаны, наполненный дисгармонией, какофонией, атональностью и джазовыми импровизациями, что в свою очередь противоречит гармоничности, напевности и слитности музыкальных произведений религиозно-культового характера; 4) музыка И. Штрауса в начале и музыка Ф.Шуберта в конце обрамляют роман в крайних точках сюжета, демонстрируя основной вектор развития сквозного действия от «земной» сущности вальса, к духовному романтизму вокальных жанров. Здесь уместно провести параллель с аналогичной трансформацией образа поэта Ивана Николаевича Бездомного от яростного атеиста к духовно озаренной личности. Бездомный олицетворяет процесс осознания человеком своей греховной сути и вины с последующим раскаянием и покаянием. Воинствующий атеист осознанно становится верующим человеком уже почти в начале романа, когда приколол на грудь «беловатой толстовки» английской булавкой иконку; 5) ритм танца, ритм марша и вокальность - главные характеристики булгаковской «музыки в романе», а также основные жанровые и темпорально-интонационные особенности.

Таким образом, духовно-образное значение музыки в романе М.А. Булгакова «Мастер и Маргарита» почти полностью совпадает с идейным замыслом, темой и проблематикой литературного произведения в целом. Автор, создавая главный труд всей своей жизни, подобрал музыкальные моменты созвучно с замыслом романа, осознанно вкладывая определенное идейное содержание и композиционную логику. Фамилии композиторов, музыкальные жанры, названия музыкальных произведений не случайны и помимо символико-образного значения обладают контекстной функциональностью. Или как выразился профессор черной и белой магии Воланд [1, с. 229]:

Кирпич ни с того ни с сего никому и никогда на голову не свалится.

\section{1 Литература}

[1] Булгаков М.А. Мастер и Маргарита (роман) // «Я хотел служить народу... »: Проза. Пьесы. Письма. Образ писателя. - М.: Педагогика, 1991. - С. 223-491.

[2] Зряковский Н.Н. Общий курс инструментоведения. - М.: Музыка, 1976. 
[3] Левик Б.В. Музыкальная литература зарубежных стран. Выпуск IV. - М.: Музыка, 1970.

[4] Музыкальный энциклопедический словарь / Гл. редакция: Г.В. Келдыш. - М.: Советская энциклопедия, 1990.

[5] Слотердайк П. Мефістофель, або Дух, що заперечує все, і воля до знання // Критика цинічного розуму: Пер. 3 нім. - Київ: Тандем, 2002. - C. 179-187.

[6] Cmo великих композиторов / Автор-составитель Д.К. Самин.М.: Вече, 2001.

[7] Хазиев B.C. Кант и Воланд // Філософія. Культура. Жиитя: Міжвузівський збірник наукових праць. - Випуск 28. - Дніпропетровськ: Дніпропетровська державна фінансова академія, 2007. C. $45-51$. 